\title{
Iodometric determination of cystamine dihydrochloride in tablets using
}

\section{diperoxyadipic acid}

\author{
Mykola Ye. Blazheyevskiy*a, Valeriy P. Moroz ${ }^{\mathrm{b}}$ \\ a Physical and Colloid Chemistry Department, National University of Pharmacy, 53 Pushkins'ka \\ str., Kharkiv, 61002, Ukraine \\ b Analytical Chemistry Department, National University of Pharmacy, 53 Pushkins'ka str., Kharkiv, \\ 61002, Ukraine

\section{blazejowski@ukr.net}

Keywords: kinetics, oxidation, cystamine, assay, diperoxyadipic acid

The kinetics of cystamine dihydrochloride oxidation by diperoxyadipic acid (DPAA) was studied in aqueous buffer solutions of $\mathrm{pH} 2.9,6.9,8.0,8.5$ and 9.2 under second-order conditions at the temperature $293 \mathrm{~K}$. The second order rate constants, $k\left(\mathrm{~L} \mathrm{~mol}^{-1} \mathrm{~min}^{-1}\right)$ were calculated from kinetic values. A suitable mechanism scheme based on these observations was proposed. The possibility of application of DPAA as reagent for oxidimetric determination of cystamine dihydrochloride in tabtets was investigated. Cystamine dihydrochloride was determined by indirect titration with DPAA. The required amount of Cystamine dihydrochloride was dissolved in water, $\mathrm{pH} 8.0$ buffer solution and DPAA solution was added. After $7 \mathrm{~min}$, the solution was acidified. The excess DPAA was determined via iodometric titration. The advantages of the applied analytical techniques in the determination of cystamine dihydrochloride in tablets «Cystamine $0.2 \mathrm{~g} »$ was presented. The recovery of cystamine dihydrochloride was $99.32 \pm 1.45 \%$. A paired t-test showed that all results obtained for bulk drug and in tablets «Cystamine $0.2 \mathrm{~g}$ », using the proposed procedure and the official procedure respectively, agreed at the $95 \%$ confidence level.

\section{Introduction}

Cystamine dihydrochloride (cystamine hydrochloride RS-1) is an emergency radioprotection from the group of sulfurcontaining drugs [1], increases the body's resistance to ionizing radiation. The action is based on the ability of the complex to reduce the number of radicals as well as ionized and excited molecules formed in irradiated tissue as well as the ability of the drug to interact with certain enzymes and to impart resistance to ionizing radiation. Contained in the first-aid kit (AI-2) were two plastic pencil boxes each with 6 tablets (0.2 grams) of cystamine dihydrochloride. 
Cystamine dihydrochloride in pure form, tablet formulations and in biological media have been determined by a number of methods including their separation by thin-layer chromatography [2]. The analytical methods used for its determination included alkalimetric titration in non-aqueous media [3], spectrophotometry by absorption of solutions with concentrations in the range of $5.3 \times 10^{-4}$ $16.0 \times 10^{-4} \mathrm{~mol} \mathrm{~L}^{-1}$ [2] based on the reaction of cystamine with $p$-nitrophenyl-diazonium to form a red-colored diazoamino compound with subsequent photometric analysis at the wavelength of $510 \mathrm{~nm}$ [4], coulometry (1) [5-7], and finally using high-performance liquid chromatography (HPLC) method with coulometric detection [8]. Simultaneous determination of cystamine and cysteamine in cosmetics by Ion-Pairing Reversed-Phase HPLC was described [9].

A procedure was also developed for the determination of cystamine based on its quantitative reduction by formamidinesulfinic acid to cysteamine and subsequent potentiometric titration with a solution of silver nitrate using a sulfide-selective indicator electrode [10].

Like all disulfides, Cystamine is interesting substrate for oxidation reactions as it may undergo either electrophilic or nucleophilic oxidation [11]. The mode of oxidation is controlled largely by the $\mathrm{pH}$ of the reaction mixture, whereas solvent effects are minimal.
Thus, stepwise oxidation of cystamine dihydrochloride with $m$-chloroperoxybenzoic acid first gives 2-amonoethyl 2amonoethanethiolsulfinate dihydrochloride and then the corresponding thiolsulfonate [12]. In acidic or neutral solution, the oxidation follows the same mechanism as that described for the oxidation of sulfide to sulfoxide. In a basic solution, however, a nucleophilic attack of the peroxy anion takes place at the sulfur atom.

However, presently no kinetic studies have been carried out to probe the analytical aspects of the oxidation of cystamine dihydrochloride with aliphatic diperoxyadipic acid in aqueous buffer solutions.

The present communication reports the use of diperoxyadipic acid (DPAA) for the indirect titrimetric determination of cystamine. The proposed method is based on the smooth stoichiometric and quantitative oxidation of cystamine with the oxidant in aqueous solutions at the $\mathrm{pH} 7.5-8.0$ to the corresponding cystamine disulfone $\mathrm{CyS}(=\mathrm{O})_{2} \mathrm{~S}(=\mathrm{O})_{2} \mathrm{Cy}$. The excess DPAA was determined via iodometric titration.

\section{Experimental part}

\section{Reagents}

Diperoxyadipic acid (hexanebis (peroxoic acid), T mp. $+114{ }^{\circ} \mathrm{C}$ (with decom.), the content of active oxygen species (AOC) $17,4 \% ; \quad \mathrm{pKa}_{1}=7,56, \quad \mathrm{pKa}_{2}=8,68 . \quad \mathrm{M}=178.14$ $\mathrm{g} / \mathrm{mol}$. Diperoxyadipic acid prepare according to the method described in [14]. 
To determine the active oxygen content (AOC) $10.00 \mathrm{ml}$ of the aqueous solution was transferred to a $100 \mathrm{ml}$ Erlenmeyer flask to which $5 \mathrm{ml}$ of a $5 \% \mathrm{KI}$ solution and $1 \mathrm{ml}$ of hydrochloric acid was added. The solution was then shaken and allowed to stand in the dark for 3 minutes. Then the released iodine was titrated with a 0.02 mol L-1 solution of $\mathrm{Na}_{2} \mathrm{~S}_{2} \mathrm{O}_{3}$. The active oxygen content was then calculated by the equation:

$\mathrm{HOO}(\mathrm{O}) \mathrm{C}\left(\mathrm{CH}_{2}\right)_{4} \mathrm{C}(\mathrm{O}) \mathrm{OOH}+4 \mathrm{KI}+$ $2 \mathrm{H}_{2} \mathrm{SO}_{4} \rightarrow \mathrm{HO}(\mathrm{O}) \mathrm{C}\left(\mathrm{CH}_{2}\right)_{4} \mathrm{C}(\mathrm{O}) \mathrm{OH}+2 \mathrm{~K}_{2} \mathrm{SO}_{4}+$ $2 \mathrm{I}_{2}+2 \mathrm{H}_{2} \mathrm{O}$

To confirm the stability of hexanebis(peroxoic acid), one sample was kept in a self-sealing bag at room temperature. The active oxygen content of the sample was checked by iodometric titration after every 5 days. It was found that it retains its active oxygen content over a period of 45 days (17,4-17,5\%). Moreover, there was no change observed in the physical appearance, too. This confirms the stability of DPAA at room temperature. and subsequently a $1.5 \cdot 10^{-2}$ mol L ${ }^{-1}$ DPAA solution was prepared.

\section{Materials}

Cystamine

dihydrochloride

$\left(2,2^{\prime}-\right.$

Diaminodiethyl disulfide dihydrochloride; $\mathrm{C}_{4} \mathrm{H}_{14} \mathrm{C}_{12} \mathrm{~N}_{2} \mathrm{~S}_{2}, M=225.2 \mathrm{~g} \mathrm{~mol}^{-1}$ ) pharma grade (Sigma-Aldrich-02712, CAS Number 56-17-7) $\geq 98.0 \%$ (TLC). $217-225{ }^{\circ} \mathrm{C}$ (dec.). $\mathrm{pKa}=8,82$; $9,58\left(30^{\circ} \mathrm{C}\right)$.
Plastic pencil boxes containing 6 tablets (0.2 grams) of cystamine in each first-aid kit (AI2) (Pharmacon OAO (Saint-Petersburg, Russia). Standard solution with a concentration of 2,00 $\mathrm{mg} \mathrm{ml}^{-1}$ cystamine dihydrochloride prepared by dissolving $0.2030 \mathrm{~g}$ of the $98.5 \%$ substance «Cystamine dihydrochloride» in double-distilled water in a volumetric flask with a capacity of $100 \mathrm{ml}$. The solution is stable for two weeks when stored in a refrigerator.

Other chemicals and reagents such as hydrochloric acid and KI used were of analytical grade from Qualigens. All reagents and solutions were prepared using this doubly distilled water.

Diluted hydrochloric acid was prepared with $0.1 \mathrm{~mol} \mathrm{~L}^{-1}$ Normadose ${ }^{\circledR}$ (standard titre).

Potassium iodide 5\% solution: $5.0 \mathrm{~g}$ of potassium iodide was dissolved in $50 \mathrm{ml}$ of freshly boiled and cooled water. It is then filled with the same solvent to $100 \mathrm{ml}$. The solution should be colourless.

Sodium thiosulphate standard solution: $\left.c\left(\mathrm{Na}_{2} \mathrm{~S}_{2} \mathrm{O}_{3} \cdot 5 \mathrm{H}_{2} \mathrm{O}\right)=0,1 \mathrm{~mol} \mathrm{~L}^{-1}\right)$, was prepared with $0.1 \mathrm{~mol} \mathrm{~L}^{-1}$ Normadose ${ }^{\circledR}$ (standard titre) in freshly boiled and cooled distilled water with addition of $0.5 \mathrm{~g}$ sodium carbonate in a $1 \mathrm{~L}$ volumetric flask. It is then filled with the same solvent to the mark at $293 \mathrm{~K}$.

The preparation of $p H$ buffer solutions. For $\mathrm{pH}=2.9$ : dissolve $12.0 \mathrm{~g}$ of anhydrous sodium dihydrogen phosphate in distilled water, adjust the $\mathrm{pH}$ with dilute phosphoric acid (100 g $\left.\mathrm{L}^{-1}\right)$ and dilute to $1000 \mathrm{ml}$ with distilled water. 
For $\mathrm{pH}=6.9$ : dissolve $90.7 \mathrm{~g}$ of dipotassium hydrogen phosphate $\left(\mathrm{K}_{2} \mathrm{HPO}_{4}\right)$ and $38 \mathrm{~g}$ of anhydrous sodium dihydrogen phosphate $\left(\mathrm{KH}_{2} \mathrm{PO}_{4}\right)$ in 1 liter volume distilled water.

$0.2 \mathrm{~mol} \mathrm{~L}^{-1}$ solution potassium pyrophosphate: dissolve $66.067 \mathrm{~g}$ potassium pyrophosphate (potassium diphosphate) in 1liter volume distilled water.

Preparation method of $\mathrm{pH}$ buffers with 8.0, 8.5 and 9.2 values included: dripping of diluted hydrochloric acid into an aqueous solution of $0.2 \mathrm{~mol} \mathrm{~L}^{-1}$ solution potassium pyrophosphate while measuring the $\mathrm{pH}$ with a $\mathrm{pH}$ meter.

For maintaining the desired temperature of the reaction mixture we used air thermostat TS- $80 \mathrm{~m}$.

Microburette $10 \mathrm{ml}, 0.01 \mathrm{ml}$ graduation. Kinetics of S-oxidation reaction-procedure:

Dissolve $0.2295 \mathrm{~g}$ of powder of cystamine dihydrochloride in double-distilled water and dilute to $100 \mathrm{ml}$. Transfer using a pipette an accurately measured volumes $(5 \mathrm{ml})$ of prepared solution to $100-\mathrm{ml}$ measuring flask, add $10 \mathrm{ml}$ of $0.015 \mathrm{~mol} \mathrm{~L}^{-1}$ previously prepared solution of the diperoxyadipic acid, $\mathrm{pH}$ buffer solution $(80 \mathrm{ml})$ and double-distilled water to bring the final volume of solution to $100 \quad m L$. Mix to homogeneity (start stopclock). Using a pipette, over a determined period of time, transfer 10.00 $\mathrm{ml}$ to the reaction mixture in $150 \mathrm{ml}$ Erlenmeyer flask. Add $2 \mathrm{ml}$ of diluted hydrochloric acid and $5 \mathrm{ml}$ of $5 \%$ solution of potassium iodide while shaking. The formed iodine is titrated with 0.01 mol L-1 sodium thiosulphate using microburette till the mixture turns colourless. Repeat the titration without cystamine dihydrochloride (control titration).

\section{Kinetic measurements}

Kinetic studies were carried out in buffer solutions under second-order conditions with diperoxyadipic acid (DPAA) in the temperature $293 \mathrm{~K}$. The reaction was followed by estimating the unreacted DPAA as a function of time by using the iodometric method. The liberated iodine was titrated against standard sodium thiosulphate solution by using starch as an indicator. From the titration values, plots of $1 / c$ vs. time were made and from the slope of such plots, the second order rate constants, $k_{\text {obs }}(\mathrm{L}$ $\mathrm{mol}^{-1} \min ^{-1}$ ) were obtained. $c$ is the current molar concentration of DPAA (for time $t, \mathrm{~min}$ ), mol $\mathrm{L}^{-1}$. It was checked that the results were reproducible within $\pm 5-10 \%$ error.

To determine the stoichiometry of the reaction, peroxy acid titration of standard solutions was carried out.

Procedure of determination cystamine dihydrochloride : Add an aliquot (1.0-4.0 mg) of sample solution or $0.5-2.0 \mathrm{ml}$ of standard solution $\left(2.0 \mathrm{mg} \mathrm{ml}^{-1}\right)$ to a known volume $(10 \mathrm{ml})$ of $0.005 \mathrm{~mol} \mathrm{~L}^{-1}$ DPAA solution, $1.0 \mathrm{ml}$ of 0.05 mol L-1 $\mathrm{NaOH}$ solution and $20 \mathrm{ml}$ of $\mathrm{pH}$ buffer solution in glass-stopper Erlenmeyer Flask. Shake the mixture occasionally and, after $7 \mathrm{~min}$, add $5 \mathrm{ml}$ of $0.1 \mathrm{~mol} \mathrm{~L}^{-1}$ hydrochloric acid and 5 
$\mathrm{ml}$ of $5 \%$ potassium iodide solution while shaking. Titrate the liberated iodine with a 0.02 mol L-1 sodium thiosulphate solution $\left(V_{2}\right)$. Carry out a blank experiment in the same manner $\left(V_{1}\right)$.

Similarly, an experiment is performed with a solution of a working Standard sample of cystamine dihydrochloride with a previously known content of the basic substance $(w, \%)$.

Calculate the amount of the cystamine from the equation cystamine dihydrochloride $\mathrm{X}(\mathrm{mg})=\left[\left(V_{1}-V_{2}\right) \times \mathrm{m}(\right.$ St. $\left.) \times w\right] \times 10 /\left[\left(V_{1}(\right.\right.$ St. $)-$ $V_{2}(\mathrm{St}.) \times 100 \%$ ], where $V_{1}$ is the volume of sodium thiosulphate consumed in the blank titration $(\mathrm{ml}) ; V_{2}$ is the volume of sodium thiosulphate consumed in the work experiment (ml); $V_{1}$ (St.) is the volume of sodium thiosulphate consumed in the blank titration in the experiment without of the Standard solution (ml); $V_{2}$ (St.) is the volume of sodium thiosulphate consumed in the experiment with Standard solution (ml); $\mathrm{m}(\mathrm{St}$.$) - weight of the$ standard «cystamine dihydrochloride» sample respectively, $m g ; w$ - content of the basic substance in cystamine dihydrochloride standard, \%.

Assay of cystamine dihydrochloride in tablets «Cystamine 0.2 g». Dissolve about 0.25 g, accurately weighed, of powder tablets of cystamine dihydrochloride in $15-20 \mathrm{ml}$ of distilled water. The slurry was filtered through a paper filter into a $100 \mathrm{ml}$ volumetric flask, washed several times and water to bring the final volume of solution to $100 \mathrm{~mL}$. Transfer using a pipette an accurately measured volume $(10 \mathrm{ml})$ of prepared solution to $100-\mathrm{ml}$ measuring flask, add $20 \mathrm{ml}$ of $0.02 \mathrm{~mol} \mathrm{~L}^{-1}$ previously prepared solution of the diperoxyadipic acid, $\mathrm{pH}$ buffer solution $(60 \mathrm{ml})$ and water to bring the final volume of solution to $100 \quad m L . \quad$ Mix to homogeneity (start stopclock). Using a pipette, over a determined period of time ( $7 \mathrm{~min})$, transfer $10.00 \mathrm{ml}$ to the reaction mixture in $150 \mathrm{ml}$ Erlenmeyer flask. Add $5 \mathrm{ml}$ of diluted hydrochloric acid and $5 \mathrm{ml}$ of $5 \%$ solution of potassium iodide while shaking. The formed iodine is titrated with $0.02 \mathrm{~mol} \mathrm{~L}^{-1}$ sodium thiosulphate using microburette till the mixture turns colourless $\left(\mathrm{V}_{2}\right)$. Repeat the titration without cystamine dihydrochloride (control titration, $\mathrm{V}_{1}$ ).

Similarly, an experiment is performed with a solution of a working Standard sample of cystamine dihydrochloride.

Transfer using a pipette an accurately measured volume $(10 \mathrm{ml})$ of prepared Standard solution $2.0 \quad \mathrm{mg} \quad \mathrm{ml}^{-1}$ of cystamine dihydrochloride in 100-ml measuring flask, add $20 \mathrm{ml}$ of $0.02 \mathrm{~mol} \mathrm{~L}^{-1}$ previously prepared solution of the diperoxyadipic acid, $\mathrm{pH}$ buffer solution $(60 \mathrm{ml})$ and water to bring the final volume of solution to $100 \quad m L$. Mix to homogeneity (start stopclock). Using a pipette, over a determined period of time ( $7 \mathrm{~min})$, transfer $10.00 \mathrm{ml}$ to the reaction mixture in $150 \mathrm{ml}$ Erlenmeyer flask. Add $5 \mathrm{ml}$ of diluted hydrochloric acid and $5 \mathrm{ml}$ of $5 \%$ solution of potassium iodide while shaking. The formed 
iodine is titrated with $0.02 \mathrm{~mol} \mathrm{~L}^{-1}$ sodium thiosulphate using microburette till the mixture turns colourless $\left(V_{2}(\mathrm{St}).\right)$. Repeat the titration without cystamine dihydrochloride (control titration, $\left.V_{1}(\mathrm{St}).\right)$.

Calculate the amount of the cystamine from the equation cystamine dihydrochloride $\mathrm{X}(\mathrm{g})=\left[\left(V_{1}-V_{2}\right) \times \mathrm{m}(\mathrm{St}.) \times \mathrm{m} \times w\right] /\left[\left(V_{1}(\mathrm{St})-.V_{2}\right.\right.$ (St.) $\times \mathrm{m}_{1} \times 100 \%$, where $V_{1}$ is the volume of sodium thiosulphate consumed in the control titration $(\mathrm{ml}) ; V_{2}$ is the volume of sodium thiosulphate consumed in the work experiment $(\mathrm{ml}) ; \quad V_{1}$ (St.) is the volume of sodium thiosulphate consumed in the control titration in the experiment without of the Standard solution $(\mathrm{ml}) ; \quad V_{2}(\mathrm{St}$.$) is the volume of sodium$ thiosulphate consumed in the experiment with Standard solution $(\mathrm{ml}) ; w$ - content of the basic substance in cystamine dihydrochloride standard, \%; $\mathrm{m}_{1}, \mathrm{~m}$ and $\mathrm{m}(\mathrm{St}$.) - weight of powder tablets of cystamine dihydrochloride, average weight of a tablet and weight of the standard «Cystamine dihydrochloride» sample respectively in $\mathrm{g}$.

\section{Results and discussion}

Investigation of the kinetic dependence on $\mathrm{pH}$ of the cystamine-diperoxyadipic acid reaction at $293 \mathrm{~K}$ and over $\mathrm{pH}$ range 2.9 to 9.2 yields bimolecular rate constants $\left(\mathrm{mol}^{-1} \mathrm{~L} \mathrm{~min}\right.$ 1).

Figure 1 shows a typical cystamine oxidation kinetic curve. It was found that one mole of cystamine dihydrochloride react with two moles of diperoxyadipic acid. The optimum for the cystamine dihydrochloride determination was $\mathrm{pH}$ 7,5 - 8.0 (time of quantitative interaction is 7-10 $\mathrm{min}$ ).

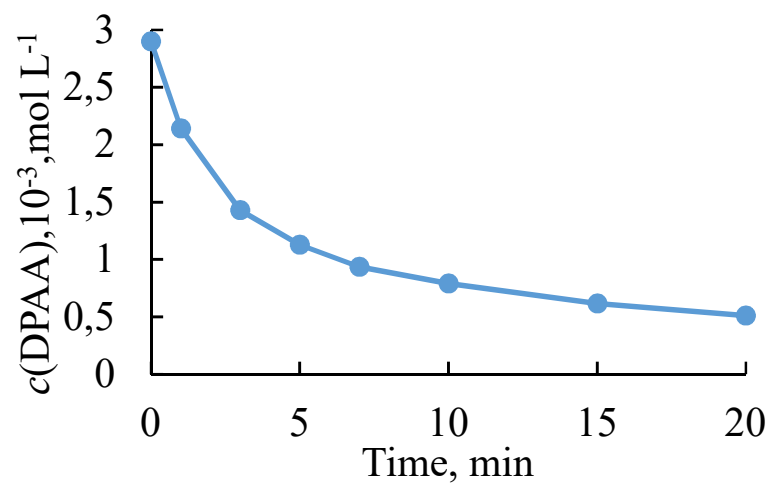

Figure 1. Concentration versus time plot of diperoxyadipic acid during the oxidation of cystamine. $\mathrm{pH}=8,0$; $c($ DPAA $)=2.9 \cdot 10^{-3} \mathrm{~mol} \mathrm{~L}^{-1} ; c($ cystamine $)=5 \cdot 10^{-4} \mathrm{~mol} \mathrm{~L}^{-1}$.

$\mathrm{pH}$ effects on the kinetics of the cystaminediperoxyadipic acid reaction shown in Figure 2.

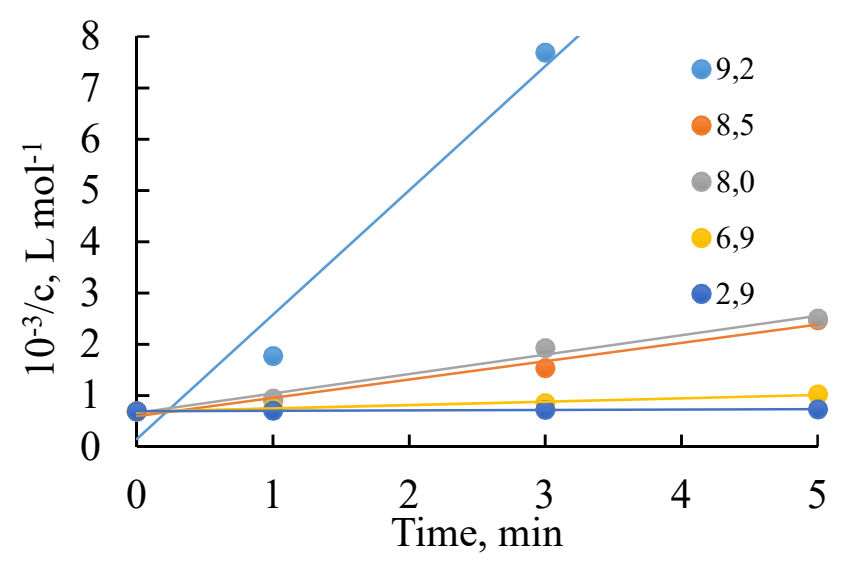

Figure 2. $\mathrm{pH}$ effects on the kinetics of the cystaminediperoxyadipic acid reaction. $\mathrm{pH}$ : 2,9-9,2. $c($ DPAA $)=1.45 \cdot 10^{-3} \mathrm{~mol} \mathrm{~L}^{-1} ; c($ cystamine $)=1 \cdot 10^{-3} \mathrm{~mol} \mathrm{~L}^{-1}$. $293 \mathrm{~K}$

The observed rate constant $k_{\text {obs }}$ is reasonably constant over the all period of cystamine oxidation by diperoxy acid mono- and dianions to the corresponding of cystamine disulfone $\quad\left(\mathrm{CyS}(=\mathrm{O})_{2} \mathrm{~S}(=\mathrm{O})_{2} \mathrm{Cy}\right)$. A suitable mechanism scheme based on these observations 
is proposed and given in the following equations

(Scheme 1):

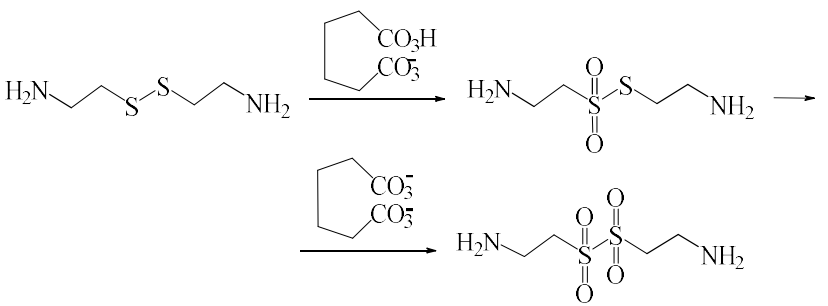

Scheme 1. The reaction mechanism of oxidation Cystamine dihydrochloride with Diperoxyadipic acid

This, in particular, points to a linear dependence of the observed reaction rate constant on the mole fraction of the sum of the mono- and dianions of the diperoxy acid (Figure

3)

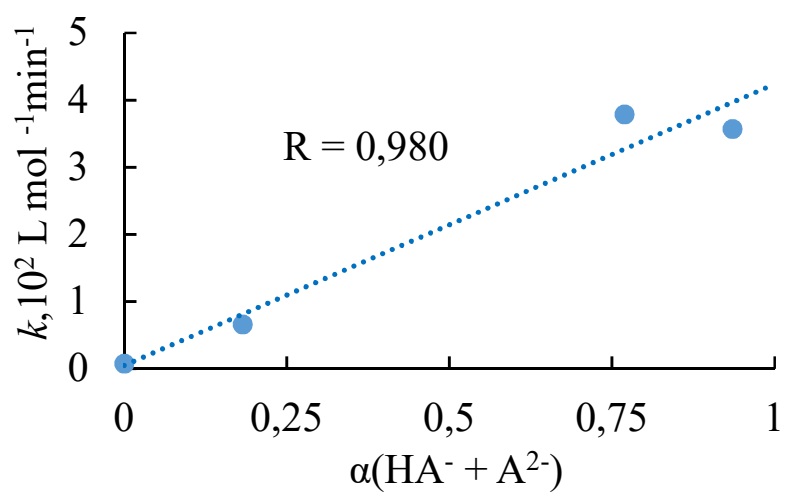

Figure 3. The dependence of the observed reaction rate constant on the mole fraction of the sum of the mono- and dianions of the diperoxy acid $(r=0.980)$

To determine the concentration of cystamine dihydrochloride, iodometric back titration method was proposed. The method is based on the oxidation of cystamine dihydrochloride by an excess of DPAA. Then, unreacted DPAA after acidification reacts with potassium iodide to form iodine, which is titrated with a standard sodium thiosulfate solution.
Table 1. Determination of concentration of cystamine dihydrochloride acid by iodometric back titration method with use diperoxy adipic acid as oxidizing agent

\begin{tabular}{|c|c|c|c|}
\hline $\begin{array}{c}\text { cystamine } \\
\text { dihydrochlo- } \\
\text { ride mg } \\
\text { taken }\end{array}$ & $\begin{array}{c}\text { cystamine } \\
\text { dihydrochlo- } \\
\text { ride mg } \\
\text { found, }\end{array}$ & $\mathrm{RSD}, \%$ & $\delta, \%$ \\
$\bar{X} \pm \Delta \bar{X}$ & $0.99 \pm 0.02$ & 1.61 & -1.0 \\
\hline 1.0 & $2.00 \pm 0.03$ & 1.21 & 0 \\
2.0 & $3.98 \pm 0.04$ & 0.80 & -0.5 \\
\hline
\end{tabular}

* Average of 5 determinations $(\mathrm{P}=0.95) . \delta=(\bar{x}-\mu)$ $100 \% / \mu$

Table 1 shows the results obtained by the recommended procedure for five replicate titrations of mixtures containing the four species at various concentrations. It can be seen that cystamine dihydrochloride could be determined successively with good accuracy and reproducibility.

The advantages of the applied analytical techniques in the determination of cystamine dihydrochloride acid in tablets «Cystamine 0.2 g» has been presented. The recovery of Cystamine dihydrochloride was $99.32 \pm 1.45 \%$. A paired t-test showed that all results obtained for cystamine dihydrochloride acid in pharmaceutical product using the proposed 
procedure and the official procedure agreed at the 95\% confidence level (Table 2).

Table 2. Determination of cystamine dihydrochloride in tablets «Cystamine 0.2 g» by iodometric method using diperoxyadipic acid

\begin{tabular}{|c|c|c|}
\hline $\begin{array}{c}\text { Content of } \\
\text { cystamine } \\
\text { dihydro- } \\
\text { chloride, g }\end{array}$ & $\begin{array}{c}\text { cystamine } \\
\text { dihydrochlo- } \\
\text { ride found, } \bar{X} \\
\text { (a recovery) }\end{array}$ & $\begin{array}{c}\text { Metrological } \\
\text { characteristics } \\
(n=5 ; \mathrm{P}=0.95)\end{array}$ \\
\hline $0.2065^{*}$ & $\begin{array}{c}0.2051 \pm 0.0030 \mathrm{~g} \\
(99.32 \pm 1.45 \%)\end{array}$ & $\begin{array}{c}\mathrm{RSD}=1.18 \% \\
(\delta=-0.68)\end{array}$ \\
\hline
\end{tabular}

*Spectrophotometric method data [2], $\mu$.

$\delta=(\bar{x}-\mu) 100 \% / \mu$

\section{Conclusions}

The kinetic studies of oxidation of cystamine dihydrochloride by diperoxyadipic acid (DPAA) have been carried out in water medium under second-order conditions in the temperature $293 \mathrm{~K}$. The second order rate constants, $k_{o b s}\left(\mathrm{~L} \mathrm{~mol}^{-1} \mathrm{~min}^{-1}\right)$ have been calculated from kinetic values. A suitable mechanism scheme based on these observations was proposed. The possibility of application of DPAA as reagent in the oxidimetric determination of cystamine dihydrochloride was investigated. The proposed method is based on the smooth and quantitative oxidation of cystamine dihydrochloride with the oxidant in aqueous media to the corresponding disulfone cystamine $\left(\mathrm{CyS}(=\mathrm{O})_{2} \mathrm{~S}(=\mathrm{O})_{2} \mathrm{Cy}\right)$. The excess DPAA was iodometry titrated applying either visual end-point detection. With this proposed method, 1.0-4.0 $\mathrm{mg}$ of cystamine dihydrochloride can be accurately and precisely analyzed ( $\mathrm{RSD}<1.6 \%, \delta<\mathrm{RSD})$. The advantages of the applied analytical techniques in the determination of cystamine dihydrochloride using diperoxyadipic acid in tablets «Cystamine 0.2 g» has been presented. The recovery of cystamine dihydrochloride was $99.32 \pm 1.45 \%$. Statistical analysis of the results obtained by the proposed and the official methods reveals no significant differences between them in accuracy and precision as concluded from Student's $t$ test and the variance ratio.

\section{References}

[1] Mashkovskiy MD. Lekarstvennyie sredstva [Medicinal products]. 16-e izd. pererab., ispravl. i dop. Moscow: Novaya volna; 2012. 1216 p.

[2] Trohimchuk VV, Chakchir BA, Hveschuk PF, Alekseev VV. Kontrol kachestva tsistamina digidrohlorida $\mathrm{v}$ protsesse hraneniya [Quality control of cystamine dihydrochloride during storage]. Farmatsiya. 1985;1:33-5.

[3] Tabletki tsistamina 0,2. Farmokopeynaya Statya. 42-237-72.

[4] Metodicheskie ukazaniya po spektrofotometricheskomu izmereniyu kontsentratsii bis-(beta-aminoetil)-disulfida digidrohlorida (Tsistamina) v vozduhe rabochey zonyi [Methodical instructions for spectrophotometric measurement of the concentration of bis(beta-aminoethyl) disulfi de dihydrochloride (Tsystamine) in the air of the work area]. MUK 41814-99.

[5] Sakharov AA. Quantitative coulometric determination of cystamine. Pharm Chem J. 1978;12(8):1094-8. 
[6] Ciesielski W, Skowron M. Coulometric Titration of Disulfides with Electrogenerated Chlorine. Chem Anal Wars. 2005;50:47-53.

[7] Danevich VI, Bureneva MI. Okislitelnovosstanovitelnoe titrovanie [Oxidation-reduction titration]. SPb.: SPHFA; 2001. 44 p.

[8] Pinto JT, Khomenko T, Szabo S, McLaren GD, Denton TT, Krasnikov BF, et al. Measurement of sulfur-containing compounds involved in the metabolism and transport of cysteamine and cystamine. Regional differences in cerebral metabolism. J Chromatogr $\quad$ B. 2009 Oct;877(28):3434-41.

[9] Kim Y, Na DH. Simultaneous Determination of Cysteamine and Cystamine in Cosmetics by IonPairing Reversed-Phase High-Performance Liquid Chromatography. Toxicol Res. 2019 Apr $15 ; 35(2): 161-5$.

[10] Karandi IV, Buzlanova MM. Potentsiometricheskoe opredelenie organicheskih disulfidov $\quad \mathrm{S}$ ispolzovaniem formamidinsulfinovoy kislotyi $\mathrm{v}$ kachestve vosstanovitelnogo agenta [Potentiometric determination of organic sulphides using formamidine sulfinic acid as a reducing agent]. Zhurnal Anal Him. 1999;54(8):848-50.

[11] Ariëns EJ, editor. Drug Design: Medicinal Chemistry: A Series of Monographs. Vol. 6. Elsevier; 2017. 382 p.

[12] Klayman DL, Milne GWA. 2-Amino-s 2 thiazolines from Aminoethyl Thiosulfates. The Mass Spectra of 2-Amino- $\Delta 2$-thiazolines and Related Compounds. J Org Chem. 1966 Jul;31(7):2349-55.

[13] Smith M, March J. March's advanced organic chemistry: reactions, mechanisms, and structure. 6th ed. Hoboken, N.J: Wiley-Interscience; 2007. $2357 \mathrm{p}$.
[14] Parker WE, Witnauer LP, Swern D. Peroxides. IV. 2 Aliphatic Diperacids. J Am Chem Soc. 1957 Apr;79(8):1929-31. 